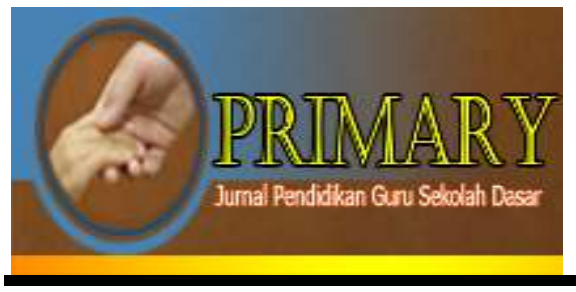

\author{
PRIMARY: JURNAL PENDIDIKAN GURU SEKOLAH DASAR \\ VOLUME 10 NOMOR 3 JUNI 2021 \\ ISSN : 2303-1514 | E-ISSN : 2598-5949 \\ DOI : http://dx.doi.org/10.33578/jpfkip.v10i3.8159 \\ https://primary.ejournal.unri.ac.id/index.php/JPFKIP
}

\title{
LEARNING READING SKILLS: PROBLEMS AND SOLUTIONS
}

\author{
Cicilia Ovavia $^{1}$, Elfia Sukma $^{2}$ \\ ${ }^{1,2}$ Universitas Negeri Padang, Kota Padang, Indonesia \\ 1ciciliaovavia@gmail.com, ${ }^{2}$ elfiasukma105@gmail.com
}

\section{PEMBELAJARAN KETERAMPILAN MEMBACA: PROBLEMATIKA DAN SOLUSINYA}

\begin{abstract}
ARTICLE HISTORY
ABSTRACT

Abstract: Reading as a literacy activity is a key to advancing education. Learning to read becomes crucial at elementary schools in order to increase students' language skills which support other learning. Based on the results of interviews and observations, there was a problem that in learning Bahasa Indonesia at elementary schools, thestudents' reading skills were low because the teacher only used the lecture method and books as a guide for students in reading skills. As a result, students were lazy to read and to understand the information contained in the books. This study was conducted to find out problems teachers and students faced in reading lessons at elementary schools. This study used qualitative descriptive research

Submitted:

5 Januari 2021

$5^{\text {th }}$ January 2021 involving grade III students of SDN 08 Mandeh. The informants were selected by using the snowball sampling technique. This study prioritized direct data from informants and observations made in the field. The object of this study was the students' reading skills in learning Bahasa Indonesia at elementary schools. The data in the study were collected through observation, interviews and documentation. Based on the data from observations, interviews and documentation, the researchers obtained solutions to the problems found in Reading Skills. The solutions were using attractive learning media, appropriate learning models, choosing various reading materials, providing motivation and feedback, and encouragement from parents.
\end{abstract}

Keywords: Problems, Reading Skills, Solutions

Accepted:

24 Mei 2021

$24^{\text {nd }}$ May 2021

Published:

26 Juni 2021

$26^{\text {th }}$ June 2021

\begin{abstract}
Abstrak: Membaca merupakan kegiatan aktivitas literasi ialah kunci untuk memajukan pendidikan., Pentingnya belajar membaca di sekolah dasar yang bisa meningkatnya kemampuan dalam berbahasa siswa yang menunjang di pembelajaran lainnya. Dari hasil wawancara dan observasi terdapat permasalahan bahwa pelajaran Bahasa Indonesia di SD terutama keterampilan membaca siswa rendah, sebab guru hanya memakai metode ceramah dan buku sebagai panduan siswa dalam keterampilan membaca. Akibatnya siswa malas untuk membaca serta memahami informasi yang ada dalam buku siswa. Penelitian ini dilakukan agar dapat diketahui masalah-masalah apa saja yang dihadapkan guru maupun siswa pada pembalajaran membaca di sekolah dasar, yang mana subjek penelitian siswa kelas III SD Negeri 08 Mandeh dengan menggunakan penelitian deskrptif kualitatif dengan subjek penelitian siswa kelas III SDN 08 Mandeh. Pemilihan informan dalam penelitian ini diperoleh dengan teknik snowball sampling. Penelitian ini mengutamakan data langsung dari informan dan observasi yang dilakukan di lapangan. Objek penelitian ini adalah keterampilan membaca siswa dalam pembelajaran Bahasa Indonesia di SD. Data dalam penelitian dikumpulkan dengan observasi, wawancara dan dokumentasi. Sehingga peneliti telah mendapatkan solusi dari masalah yang terdapat di Keterampilan Membaca. Solusinya dengan menggunakan media pembelajaran yang menarik, model pembelajaran yang tepat, memilih bahan bacaan yang bervariasi,memberi motivasi dan umpan balik,serta dorongan dari orang tua.
\end{abstract}

Kata Kunci: Problematika, Keterampilan Membaca, Solusi

\section{CITATION}

Ovavia, C., \& Sukma, E. (2020). Learning Reading Skills: Problems and Solutions. Primary: Jurnal Pendidikan Guru Sekolah Dasar, 10 (3), 575-581. DOI: http://dx.doi.org/10.33578/jpfkip.v10i3.8159. 


\section{PENDAHULUAN}

Pendidikan merupakan sesuatu penentu supaya bangsa kita bisa melangkah lebih maju serta bisa bersaing dengan negaranegara yang lain. Menurut Hamalik (2013:3), "pendidikan adalah suatu proses dalam rangka mempengaruhi siswa supaya mampu menyesuaikan diri sebaik mungkin dengan lingkungannya, dan dengan demikian akan menimbulkan perubahan dalam dirinya yang memungkinkannya untuk berfungsi secara adekuat dalam kehidupan bermasyarakat."

Pembelajaran dapat diartikan sebagai proses membuat orang belajar, dari tidak mengetahui sesuatu menjadikan orang itu bisa tahu. Menurut Susanto (2013:242)," Pembelajaran Bahasa Indonesia di sekolah mencakup empat keterampilan berbahasa, yaitu menyimak, berbicara, membaca dan menulis."Pembelajaran bahasa Indonesia bertujuan untuk membimbing siswa agar bisa berprestasi dengan efektif dan efisien komunikasi berdasarkan norma dan aturan umum yang diterapkan di masyarakat, baik tertulis maupun tidak (Gautama, Ramadhan, and Abdurahman 2018)

Keterampilan berbahasa merupakan bagian pendidikan merupakan tiap aktivitas yang dirancang oleh guru agar dapat menolong seorang menekuni sesuatu keahlian ataupun nilai yang baru dalam sesuatu proses yang sistematis lewat rancangan, penerapan, serta penilaian dalam konteks aktivitas proses belajar. Membaca adalah sesuatu proses yang dilakukan serta digunakan oleh pembaca untuk memperoleh pesan, yang hendak disampaikan oleh penulis melalui media kata-kata/bahasa tulisan berarti dalam kehidupan. "Keahlian membaca sangat berarti dalam kehidupan, sebab tiap aspek kehidupan tidak luput dari aktivitas membaca. Oleh sebab itu belajar membaca wajib lekas dipahami oleh para siswa di SD sebab membaca ini secara langsung berkaitan dengan segala proses belajar siswa di SD. Siswa yang tidak sanggup membaca dengan baik hendak di hadapi kesusahan dalam menjajaki aktivitas dalam pembelajaran buat seluruh mata pelajaran. Siswa hendak di hadapi kesusahan dalam menangkap serta menguasai materi yang disajikan dalam bermacam buku teks pelajaran, buku- buku bahan penunjang serta sumber- sumber belajar yang lain, akibat kesusahan membaca tersebut kemajuan belajarnya pula lamban bila dibanding dengan sahabatnya yang tidak hadapi kesusahan dalam membaca."(Rahman and Haryanto 2014).

Belajar membaca dapat diperoleh dimana saja, pembelajaran membaca pada biasanya diterima dengan metode belajar di dalam kelas yaitu sekolah. "Keahlian berbahasa ini ialah sesuatu keahlian yang sangat unik dan berfungsi untuk pengembangan pengetahuan, serta perlengkapan komunikasi untuk kehidupan manusia. Bahasa dikatakan unik sebab tidak seluruh manusia meski sudah mempunyai kepandaian membaca, secara mudah bisa mengembangkannya buat memberdayakan dirinya ataupun apalagi menjadikannya budaya untuk dirinya sendiri.Membaca dikatakan berarti untuk pengembangan pengetahuan sebab persentase transfer ilmu pengetahuan paling banyak ditemukan lewat membaca."(Rahman and Haryanto 2014)

Perkembangan ilmu pengetahuan serta teknologi menuntut terciptanya warga yang gemar belajar. Proses belajar yang efisien antara lain dicoba lewat membaca. Warga yang gemar membaca mendapatkan pengetahuan serta pengetahuan baru yang hendak terus menjadi tingkatkan kecerdasannya sehingga mereka lebih sanggup menanggapi tantangan hidup pada masa- masa mendatang.

Sekolah bagaikan sesuatu lembaga pendidikan formal, secara sistematis merancang beragam lingkungan, ialah lingkungan pembelajaran yang sediakan bermacam peluang siswa buat melaksanakan bermacam aktivitas belajar. Dengan bermacam peluang belajar itu, pertumbuhan serta perkembangan siswa ditunjukan serta didorong ketercapaian tujuan yang di cita- citakan. Lingkungan tersebut disusun serta ditata dalam 
sesuatu kurikulum, yang pada gilirannya dilaksanakan dalam wujud proses pembelajaran. Tujuan pendidikan pada dasarnya merupakan seperangkat hasil pendidikan oleh peserta didik setelah diselenggarakan kegiatan pendidikan. "Dalam proses kegiatan perencanaan pembelajaran, guru sudah selayaknya mampu dalam memilih bahan ajar, media pembelajaran dan membuat siswa untuk membaca buku-buku yang berkualitas, karena kegiatan membaca ini sejalan dengan proses berpikir kritis yang membuat terbentuknya daya cipta dan kreativitas peserta didik" (Kurniawan et al. 2019). Namun dalam penerapan, masih didapatkan berbagai macam kesulitan yang ditemukan guru .

Proses belajar mengajar berlangsung tidak lepas dari peranan guru dalam proses berlangsungnya pembelajaran didalam kelas, mampu atau tidak guru dalam menciptakan pembelajaran menarik sehingga siswa antusias dalam pembelajaran.

Namun, pada saat observasi dan wawancara terdapat permasalahan di sekolah dasar, dalam proses membaca atau pembelajaran membaca mata pelajaran bahasa indonesia. Permasalahan ini tidak dapat dibiarkan , jika dibiarkan akan mengakibatkan tidak seimbangnya pola pikir siswa dalam proses pembelajaran atau tidak mampu siswa dapat berpikir kritis. Dalam permasalah tersebut diperlukan solusi untuk mengatasi permasalahan ini, penelitian memiliki keinginan untuk membahas tentang problematika dalam pembelajara membaca serta solusinya.

\section{METODE PENELITIAN}

Peneltian ini merupakan penelitian deskriptif kualitatif. Penelitian kualitatif adalah metode penelitian yang berlandaskan pada filsafat postpositivisme, yang lebih menekankan pada aspek pemahaman secara mendalam terhadap suatu fenomena. (Anon 2020). Pendekatan kualitatif ini digunakan untuk menguraikan, menggambarkan, menggali dan mendeskripsikan yang berkaitan dengan penelitian ini.

Penelitian ini dilaksanakan pada bulan 2 November - 3 November 2020. Tempat penelitian dilaksanakan UPT.SD Negeri 08 Mandeh. Subjek penelitan dalam penelitian ini adalah siswa/siswi kelas III sebanyak 20 siswa. Pemilihan informan dalam penelitian ini diperoleh dengan teknik snowball sampling. Penelitian ini mengutamakan data langsung dari informan dan observasi yang dilakukan di lapangan. Objek penelitian ini adalah aktivitas yang dilakukan siswa. (Magister et al. 2020)

Teknik pengumpulan datanya dengan triangulasi. Sugiono (2015: 309) menyatakan "teknik pengumpulan data dapat dilakukan dengan observasi (pengamatan), interview (wawancara), kuesioner (angket), dokumentasi dan gabungan keempatnya". Pada penelitian ini peneliti menggunakan teknik pengumpulan data dengan menggunakan gabungan dari observasi, wawancara, dan dokumentasi. Penelitian ini merupakan jenis penelitian deskriptif. Jenis penelitian deskriptif adalah data yang dikumpulkan adalah berupa katakata, gambar, dan bukan angka. Penelitian ini untuk mengumpulkan informasi suatu gejala yang ada, yaitu gejala menurut apa adanya pada saat penelitian dilakukan dengan menggambarkan apa adanya tentang suatu variabel. Sumber data adalah segala sesuatu yang dapat memberikan informasi terkait dengan penelitian yang dilakukan. Untuk itu, agar peneliti bisa mengumpulkan data yang validitas dan realibilitas dapat dipertanggungjawabkan terkait dengan pemanfaatan perpustakaan sekolah sebagai sumber belajar siswa SD Negeri 08 Mandeh, maka sumber data tersebut yaitu guru SD Negeri 08 Mandeh. Penelitian kualitatif mengumpulkan data dengan triangulasi (gabungan) yaitu pengumpulan data (Rosmalah and RIska 2019)sebagai berikut ini : 1. Observasi

Observasi merupakan teknik pengumpulan data yang di lakukan dengan cara mengamati langsung apa yang diteliti, 
yaitu mengamati langsung pemanfaatan perpustakaan sekolah sebagai sumber belajar siswa SD Negeri 08 Mandeh. Pada penelitian ini, peneliti menggunakan pengamatan participant observer dimana peneliti berpartisipasi aktif dalam kegiatan yang diamati. Pada penelitian ini peneliti melakukan penelitian secara terang - terangan artinya informan mengetahui peneliti sedang melakukan penelitian.

2. Wawancara

Wawancara merupakan salah satu teknik yang dapat digunakan dalam pengumpulan data. Pada penelitian ini peneliti menggunakan wawancara terstruktur. Dimana wawancara terstruktur adalah suatu bentuk wawancara di mana pewawancara dalam hal ini, peneliti menyusun secara terperinci dan sistematis rencana atau pedoman pertanyaan menurut pola tertentu dengan menggunakan format yang baku secara tertulis. Teknik wawancara ini dilakukan kepada Wali kelas III SD Negeri 08 Mandeh Kabupaten Pesisir Selatan.

\section{Dokumentasi}

Dokumen dalam penelitian ini berkaitan dengan permasalahan dan solusi pada keterampilan membaca di SD Negeri 08 Mandeh.

\section{HASIL DAN PEMBAHASAN}

\section{A. Problematika dalam Keterampilan membaca \\ Keahlian membaca sangat berarti} dalam kehidupan, sebab tiap aspek kehidupan tidak luput dari aktivitas membaca. Oleh sebab itu keahlian membaca wajib lekas dipahami oleh para siswa di SD sebab keahlian ini secara langsung berkaitan dengan segala proses belajar siswa di SD. Siswa yang tidak sanggup membaca dengan baik hendaknya di hadapi kesusahan dalam menjajaki aktivitas pendidikan buat seluruh mata pelajaran. Siswa hendak hadapi kesusahan dalam menangkap serta menguasai data yang disajikan dalam bermacam buku teks pelajaran, buku- buku bahan penunjang serta sumber- sumber belajar yang lain, akibat kesusahan membaca tersebut kemajuan belajarnya lamban, bila dibanding dengan siswa yang tidak hadapi kesusahan dalam membaca.

Berdasarkan hasil observasi dan wawancara yang dilakukan peneliti dengan guru pada hari Senin tanggal 2 November 2020 dan Selasa 3 November 2020 dalam proses pembelajaran Bahasa Indonesia di kelas III SDN 08 Mandeh. Pada semester I tahun ajaran 2020/2021 ditemukan masalah dalam pembelajaran Bahasa Indonesia dengan KD 3.8 Menguraikan pesan dalam dongeng sebagai bentuk ungkapan diri menggunakan kosa kata baku dan kalimat efektif dengan indikator 3.8.1 Menemukan pesan yang terdapat dalam dongeng.

Dalam materi menemukan pesan dalam dongeng. Peneliti melihat siswa menghadapi kesulitan memahami sebuah teks dongeng sehingga susah untuk menemukan pesan di dalam dongeng. Guru hanya menggunakan media papan tulis dan teks dongeng di buku siswa, sehingga pada proses pembelajaran siswa tidak antusias dalam memahami cerita isi dongeng, siswa mondarmandir saat pembelajaran berlangsung, Permasalahan lain guru hanya menggunakan metode ceramah dan tanya jawab sehingga siswa sibuk dengan dirinya sendiri tanpa memperhatikan guru dalam menjelaskan materi tersebut. Siswa sulit memahami teks bacaan dan tidak mampu menemukan pesan yang terdapat di dalam dongeng.

\section{B. Solusi untuk mengatasi problematika keterampilan membaca}

Problematika yang ditemui dalam pembelajaran membaca sekedar problematika yang bisa dianggap sepele, tapi tidak bisa dibiarkan berlarut-larut di karenakan berdampak pada perkembangan pola pikir siswa. Guru kelas rendah umumnya harus bersungguh-sungguh dalam guru kelas rendah haruslah berusaha dengan sungguhsungguh agar guru tersebut membantu siswa yang kurang memahami dalam keterampilan membaca serta memberikan dasar 
kemampuan memadai dalam pelaksanaan pembelajaran yang baik.

Untuk mengatasi hal tersebut di atas, sebagai seorang guru tentunya memiliki tugas untuk menyiapkan pembelajaran agar siswa dapat termotivasi dalam prosess pembelajaran tentunya dalam meningkat pembelajaran membaca serta dapat memahami teks bacaan yang dibacakan siswa. Selain guru, orang tua juga peranan yang sangat perlu dalam meningkatkan motivasi belajar dalam membaca dan mengatasi masalah yang bersangkutan dengan membaca siswa di sekolah dasar. Adapun solusi untuk mengatasi permasalah tersebut diantaranya (Suastika 2019) :

1. Guru dapat menggunakan Media Pembelajaran yang menarik

Media pembelajaran dapat digunakan sebagai penunjang dalam proses pembelajaran bagi siswa untuk bisa secara cepat memahami materi yang di ajarkan. Seperti menerapkan media video animasi sesuai dengan meteri tentang menceritakan kembali isi dongeng. Sebelum siswa hanya mengenal media gambar, dengan menggunakan media video animasi yang berisikan materi dan video dongeng kelas III SD, sehingga akan menarik perhatian agar siswa tidak bosan dan antusias dalam melaksanakan proses pembelajaran. Video animasi pembelajaran merupakan video animasi yang diisi oleh materi dan video pelajaran yang dapat dijadikan media pembelajaran untuk sekolah dasar karena sifatnya dapat memusatkan perhatian, lucu serta menarik, cocok digunakan anak sekolah dasar.

2. Memilih teks atau materi bacaan

Memilih teks atau materi bacaan merupakan tugas yang dilakukan guru agar pembelajaran bisa mudah dipahami siswa, menggunakan teks bacaan yang benar atau menarik dapat memotivasi siswa untuk membaca isi teks dalam teks bacaan dengan serius untuk memahami teks tersebut. Selain itu guru harus bijaksana dalam memilih bahan bacaan yang bervariasi, menarik, seperti memiliki gambar yang bagus dan warna yang menarik sehingga siswa seanang membaca bahan bacaan yang diberikan guru. Dengan gambar yang menarik, siswa dapat pula memahami bacaan dengan cepat.

3. Menggunakan Model Pembelajaran yang pas serta menarik

Menggunakan model dalam proses pembelajaran yang pas dapat membantu guru dalam melaksanakan proses pembelajaran berlangsung seperti dalam pembelajaran membaca. Dengan menggunakan model siswa juga bisa di ajak belajar sambil bermain yang ada keterkaitannya dengan membaca.

4. Memotivasi Siswa dengan Memberikan Umpan Balik

Motivasi merupakan salah satu bentuk dorongan guru kepada siswa agar siswa memiiliki kemaun untuk mengikuti proses pembelajaran. Guru selalu berupaya agar siswa selalu bersemangat dan termotivasi melakukan pembelajaran membaca. Memotivasi siswa dalam kelas merupakan salah satu metode yang sangat berarti untuk guru supaya bisa mengenali kemajuan siswa dalam mengikuti proses belajar. Oleh sebab itu, perlunya guru memberi umpan balik kepada peserta didik saat sebelum dan sesudah melaksnanakan proses belajar.

5. Program Bimbingan bagi siswa yang sulit dalam memahami bahan bacaan

Guru bisa mengatasi permasalahan ini seperti guru hendak memberi dbimbingan diluar jam pembelajaran, memberikan bahan bacaan atau memilih bacaan yang tingkat kesulitan rendah agar siswa tersebut dapat memahami secara bertahap. Setelah siswa dapat memahami bahan bacaan yang tingkat kesulitan rendah, guru bisa memberikan kepada siswa bahan bacaan yang kesulitan rendah.

6. Bimbingan orang tua

Selain guru, orang tua juga memiliki peran penting dalam tingkat kemajuan belajar siswa dalam membaca. Siswa memerlukan bimbingan orang tua saat dirumah untuk kemajuan membaca siswa, seperti melatih siswa 
agar mereka tidak merasa tertinggal dari temannya dalam proses membaca serta memahami teks bacaan. Upaya yang dilakukan orang tua sangat membantu guru saat siswa di sekolah.

\section{SIMPULAN DAN REKOMENDASI}

Berdasarkan hasil observasi yang dilakukan peneliti dalam proses pembelajaran Bahasa Indonesia pada pembelajaran membaca, peneliti melihat siswa menghadapi kesulitan memahami sebuah teks dongeng sehingga susah untuk menemukan pesan di dalam dongeng. Guru hanya menggunakan media papan tulis dan teks dongeng di buku siswa, sehingga pada proses pembelajaran siswa tidak antusias dalam memahami cerita isi dongeng, siswa mondar-mandir saat pembelajaran berlangsung, Permasalahan lain guru hanya menggunakan metode ceramah dan tanya jawab sehingga siswa sibuk dengan dirinya sendiri tanpa memperhatikan guru dalam menjelaskan materi tersebut. Siswa sulit memahami teks bacaan dan tidak mampu menemukan pesan yang terdapat di dalam dongeng.

Berdasarkan permasalah tersebut Penelitian ini dilakukan agar dapat mengetahui apa masalah-masalah yang dihadapi oleh guru ataupun peserta didik dalam pembalajaran membaca di sekolah dasar dengan subjek penelitian siswa kelas III SD Negeri 08 Mandeh.. Sehingga peneliti telah mendapatkan solusi dari masalah yang terdapat di Keterampilan Membaca. solusinya dengan menggunakan media pembelajaran yang menarik, model pembelajaran yang tepat, memilih bahan bacaan yang bervariasi,memberi motivasi dan umpan balik,serta dorongan dari orang tua. Semua itu merupakan solusi yang dapat mengatasi maslah dalam membacaserta dapat meningkatkan kemauan siswa dalam membaca. Agar dapat mengatasi permasalahan dalam proses membaca di sekolah dasar belum tentu mudah dilaksanakan saat proses pembelajaran, perlunya kerjasama antara orang tua dan guru dalam meningkatkan keterampilan membaca siswa baik disekolah maupun pada saat berada di rumah.

\section{DAFTAR PUSTAKA}

Arikunto, S. (2012). Dasar-Dasar Evaluasi Pendidikan. Jakarta: Bumi Aksara.

Gautama, R., Ramadhan, S., and Abdurahman, A. (2018). "Effect of The Use of Cooperative Learning Approach Type Think Pair Share And Students Interest In Reading Towards Students Skill In Writing Observation Report Text." 263(Iclle):154-57. doi: 10.2991/iclle18.2018.24.

Kurniawan, A. R., Chan, F., Abdurrohim, M., Wanimbo, O., Putri, N. H., Intan, F. M., and Samosir, W. L. S. (2019). "PROBLEMATIKA GURU DALAM MELAKSANAKAN PROGRAM LITERASI DI KELAS IV SEKOLAH DASAR PENDAHULUAN Pelaksanaan Pendidikan Merupakan Salah Satu Aspek Kehidupan Yang Sangat Dibutuhkan Bagi Masyarakat Indonesia . Menurut UU No . 20 Tahun 2003 Tentang Sitem Pendidik." III(November):31-37.

Magister, Prodi, Pendidikan Dasar, Pascasarjana Universitas Jambi, and Article Information. 2020. "Peran Kepala Sekolah Dalam Meningkatkan Mutu Pendidikan Di SDN 18/III Tarutung Kabupaten Kerinci Hendra Zeki Y, Yuliana." 5(2):168-82.

Rahman, B, and Haryanto, H. (2014). "Peningkatan Keterampilan Membaca Permulaan Melalui Media Flashcard Pada Siswa Kelas I Sdn Bajayau Tengah 2." Jurnal Prima Edukasia 2(2):127. doi: 10.21831/jpe.v2i2.2650.

Rosmalah, R., and Riska, A. (2019). "Pemanfaatan Perpustakaan Sekolah Sebagai Sumber Belajar Siswa SD Inpres 12/79 Biru II Kecamatan Tanete Riattang Kabupaten Bone." JIKAP PGSD: Jurnal Ilmiah Ilmu Kependidikan 3(2):165. doi: 10.26858/jkp.v3i2.9124. 


\section{PRIMARY: JURNAL PENDIDIKAN GURU SEKOLAH DASAR \\ VOLUME 10 NOMOR 3 JUNI 2021 \\ ISSN : 2303-1514 | E-ISSN : 2598-5949 \\ DOI : http://dx.doi.org/10.33578/jpfkip.v10i3.8159 \\ https://primary.ejournal.unri.ac.id/index.php/JPFKIP}

Shoimin, A. (2014). 68 Model Pembelajaran Inovatif dalam Kurikulum 2013. Yogyakarta: Ar-Ruzz Media.

Suastika, N. S. (2019). "Problematika Pembelajaran Membaca Dan Menulis Permulaan Di Sekolah Dasar." Adi Widya: Jurnal Pendidikan Dasar 3(1):57. doi: 10.25078/aw.v3i1.905.

Susanto, A. (2014). Teori Belajar Pembelajaran di Sekolah Dasar. Jakarta: Prenada Media Group.

Sugiono. (2015). Metode Penelitian Pendidikan Pendekatan Kuantitatif, Kualitatif, dan R\&D. Bandung: Penerbit Alfabeta.

Suhandi, A. (2020). "Dampak Musim Libur Covid-19 Belajar Dari Rumah Terhadap Psikologi Anak Sekolah Dasar" 5(2):207-18. 